\title{
BUDAYA MENELITI SISWA MADRASAH MELALUI MADRASAH YOUNG RESEARCHERS SUPER CAMP
}

\section{RESEARCH CULTURE ON MADRASAH STUDENT THROUGH MADRASAH YOUNG RESEARCHERS SUPER CAMP}

\author{
Saimroh, Abdul Basid \\ Balai Penelitian dan Pengembangan Agama Jakarta \\ Jalan Rawa Kuning No.6 Pulogebang, Cakung, Jakarta Timur 13950 \\ email: saimroh@gmail.com dan abd.basid@gmail.com
}

Naskah Diterima: 17 Mei 2020; Direvisi: 25 Juni 2020; Disetujui: 6 Desember 2020

\begin{abstract}
This paper is based on a program evaluation of Madrasah Young Researchers Super Camp (MYRES). This program is a superior program from the directorate of Islamic education, Ministry of Religion Affairs since 2018. The evaluation aims to view program effectiveness for the past 2 years and giving feedback for improvement in the future. This research uses CIPP as an evaluating tool. Data had been collected from September 2019 using observation, interviews, questionnaires, and document analysis. By contextual analysis, the evaluation result shows that MYRES is aligned with regulation and people's needs. Input Evaluation shows that in general, input goals are in a good category with some improvement notes on user guidance, Grand Final Committee, research funding, and winner's development. Process evaluation shows that all stages executed in MYRES are generally well with some improvement notes on the socializing stage, exhibition location, expo, and presentation exam. Product evaluation shows that in general, MYRES's goal to develop research culture in Madrasah Student is well accomplished. This evaluation recommends MYRES to be continued with improvement as Indonesia Ministry Of Religion Affair's superior program.
\end{abstract}

Keywords: Evaluation; Madrasah; MYRES; Research culture

\begin{abstract}
Abstrak
Tulisan ini merupakan hasil penelitian evaluasi program Madrasah Young Researchers Super Camp (MYRES) yang merupakan salah satu program unggulan dari Direktorat Kurikulum, Sarana, Kelembagaan dan Kesiswaan (KSKK) Madrasah, Direktorat Jenderal Pendidikan Islam, Kementerian Agama. Program ini digelar sejak tahun 2018. Evaluasi ini bertujuan untuk melihat efektifitas program yang sudah berjalan dua tahun guna memberikan masukan untuk perbaikan program yang akan datang. Penelitian menggunakan metode evaluasi CIPP (contex, input, process, product). Pengumpulan data dilakukan pada bulan September 2019 dengan teknik observasi, wawancara, angket dan studi dokumen. Hasil evaluasi konteks menunjukkan bahwa pelaksanaan program MYRES sudah sesuai dengan amanat Undang-undang nomor 20 Tahun 2003 dan Permendiknas Nomor 39 Tahun 2008 serta dibutuhkan masyarakat madrasah. Evaluasi input program mencapai hasil baik dengan beberapa masukan pada juknis, koordinasi panitia, pembiayaan penelitian dan hadiah untuk pemenang. Evaluasi proses menunjukkan hasil yang baik dengan masukan perbaikan pada sosialisasi, lokasi pameran, dan standarisasi pameran dan ujian presentasi. Evaluasi produk membuktikan bahwa program MYRES efektif untuk menumbuhkembangkan budaya meneliti pada siswa madrasah. Hasil evaluasi ini merekomendasikan agar program MYRES dapat dilanjutkan dengan perbaikan sebagai program unggulan Kementerian Agama.
\end{abstract}

Kata kunci: Budaya meneliti; Evaluasi; Madrasah; MYRES 


\section{PENDAHULUAN}

Prestasi siswa madrasah dalam kompetisi bidang penelitian nasional dan internasional semakin menonjol. Beberapa siswa Madrasah Aliyah Negeri (MAN) 2 Sleman, Yogyakarta dan MAN 2 Pekanbaru, Riau berhasil meraih 1 medali perak dan 3 medali perunggu pada International Science Technology and Engineering Competition (ISTEC) tahun 2020 yang diikuti oleh 13 negara (Maarif, 2020). Tak kalah dengan siswa madrasah aliyah, beberapa siswa Madrasah Tsanawiyah (MTs) Surya Buana, Malang, Jawa Timur juga telah menorehkan prestasi dalam kompetisi penelitian International Young Invention Award (IYIA) pada tahun 2017 (Hasanah, 2017). Siswa MTS Negeri 2 Kota Kediri mendapatkan penghargaan untuk mengikuti program Broadcom Master International Program di Phoenix di Arizona, Amerika Serikat karena berhasil menjadi finalis dalam Lomba Karya Ilmiah Remaja (LKIR) yang digelar oleh Lembaga Ilmu Pengetahuan Indonesia (LIPI) pada tahun 2019 (Yunelia, 2019).

Pada ajang kompetisi penelitian tingkat nasional, siswa MAN 2 Kota Malang, MAN 1 Kudus, MAN Insan Cendikia Aceh, MAN 2 Kota Kediri menjadi juara dalam LKIR ke-51 tahun 2019 (Handoko, 2019). Siswa MAN 2 Kota Malang berhasil menyabet medali emas dan perunggu pada Olimpiade Penelitian Siswa Indonesia (OPSI) tahun 2019 yang diselenggarakan oleh Kementerian Pendidikan dan Kebudayaan (Wisnubro, 2019). Selain itu, hasil karya sembilan siswa MTS Negeri 2 Kediri telah tercatat memiliki hak cipta atau paten (beritaekspres.com, 2015).

Prestasi siswa madrasah dalam bidang penelitian tersebut telah tumbuh dan berkembang sejak Kementerian Agama melalui Direktorat Pendidikan Islam (Dirjen Pendis) meluncurkan program madrasah berbasis riset nasional (Promadrina) pada tahun 2013 (Amrullah, 2013). Program ini menjadi ujung tombak munculnya madrasah-madrasah berbasis riset, seperti MTS N 2 Kediri, MTS N Kota Batu Malang, MTS N 6 Sleman, MAN 1 Yogyakarta, MAN 2 Kudus, dan MAN 1 Jembrana Bali. Meskipun hingga saat ini Promadrina belum memiliki panduan atau petunjuk pelaksanaan sehingga belum ada keseragaman konsep dan implementasi antara madrasah berbasis penelitian yang satu dengan yang lainnya. Selain itu, keterbatasan anggaran penelitian pada madrasah, ruang khusus penelitian, dan tenaga pembimbing penelitian menjadi kendala dalam implementasi madrasah berbasis riset (Hidayati, 2019). Meskipun demikian, Promadrina telah mencetak penelitipeneliti muda yang kompetitif di tingkat nasional dan internasional. Mayoritas siswa madrasah yang menjadi juara kompetisi bidang riset berasal dari madrasah berbasis riset.

Kementerian Agama juga menyelenggarakan Kompetisi Sains Madrasah (KSM) sejak tahun 2012 sebagai wahana untuk mengembangkan bakat dan minat siswa madrasah di bidang sains, meningkatkan kemampuan intelektual, emosional, dan spiritual berdasarkan nilai-nilai agama, dan mengembangkan budaya kompetitif yang dipersiapkan untuk ajang kompetisi tingkat internasional (Dirjen Pendis, 2019). Kompetisi ini memiliki tiga target utama, pertama untuk mengukur kualitas pembelajaran sains di Madrasah, kedua untuk menemukan bibit penelitian sains, dan ketiga untuk menemukan hasil penelitian yang dapat dikembangkan penelitian lanjutan. Promadrina maupun KSM membuktikan komitmen Kementerian Agama untuk meningkatkan mutu dan daya saing madrasah melalui penguatan sains dan budaya penelitian.

Selain kedua program tersebut, Kementerian Agama melalui Direktorat Kurikulum, Sarana, Kelembagaan dan Kesiswaan (KSKK) Madrasah, Dirjen Pendis membuat program kompetisi penulisan karya tulis ilmiah Madrasah Young Researchers Super Camp (MYRES) yang ditujukan bagi siswa-siswa madrasah tingkat menengah dari MTs hingga MA. Kompetisi ini meliputi tiga bidang dilombakan, yaitu Ilmu matematika, sains dan pengembangan teknologi, ilmu sosial dan humaniora, dan ilmu keagamaan (Dirjen Pendis, 2019). Pada tahun 2019, kompetisi MYRES ini sudah berjalan dua tahun dan pelaksanaan grand final selalu bersamaan dengan KSM tingkat nasional. Grand final pertama diselenggarakan di Bengkulu bersamaan dengan KSM nasional ke-7 pada tanggal 24-29 September 2018 dan grand final 
kedua berlangsung di Manado, Sulawesi Utara bersamaan dengan KMS nasional ke-8 pada tanggal 16-19 September 2019.

Kompetisi MYRES pertama tahun 2018 dikuti oleh 664 proposal yang terdiri dari 378 proposal bidang matematika, sains, dan pengembangan teknologi, 203 proposal bidang sosial dan humaniora, dan 83 proposal bidang keagamaan (Oebaidillah, 2018). Selanjutnya kompetisi MYRES kedua pada tahun 2019 dengan jumlah peserta mencapai 1.018 proposal atau meningkat sebesar $65,23 \%$ dari tahun 2018. Hal ini karena semakin gencarnya sosialisasi yang dilakukan oleh Direktorat KSKK sehingga penyebaran peserta semakin luas di seluruh Indonesia (Wawancara Yuyun, 12 September 2019).

Hingga dua tahun program MYRES berjalan, belum pernah dilakukan evaluasi bagaimana ketercapaian program dengan tujuan yang telah ditetapkan. Pada studi awal, ditemukan beberapa permasalahan, pertama, adanya ketidaksesuaian atau revisi jadwal atau tidak sesuai dengan petunjuk teknis (juknis) pada Keputusan Dirjen Pendis nomor 2146 tahun 2019, kedua, peserta MYRES terkesan eksklusif untuk kalangan madrasah berstatus negeri dan berprestasi. Data peserta MYRES 2019 mencatat bahwa $93,81 \%$ proposal berasal dari siswa madrasah negeri dan hanya 6,19\% proposal dari madrasah swasta. Ketiga, MYRES kalah popular dengan KSM. Beberapa guru pendamping peserta KSM belum mengetahui adanya MYRES sehingga belum mengikuti kompetisi ini (Wawancara Yani dan Ima, 17 September 2019). Keempat, panitia tidak memberikan biaya penelitian pada tim peneliti atau siswa yang lolos ke tahap penelitian sehingga madrasah harus meng-gunakan biaya penelitian secara mandiri, bahkan sebagian menggunakan biaya pribadi dari siswa atau orang tua siswa yang bersangkutan.

Atas dasar pertimbangan itu, maka diperlukan kajian evaluasi untuk mengetahui ketercapaian program MYRES pada penyelenggaraan tahun kedua ini. Stufflebeam (1973) dalam (Tayibnapis, 2008) mendefinisikan evaluasi adalah penyediaan informasi untuk disajikan sebagai dasar berpikir dalam membuat pertimbangan pada keputusan. Evaluasi program menurut Tyler
(1950) adalah proses untuk mengetahui apakah tujuan program sudah terealisasikan. Patton (1997) dalam (Ibnu Salman, 2016) mendefinisikan evaluasi program merupakan pengambilan data yang sistematis untuk melakukan penilaian dan keputusan terhadap program. Lima hal yang perlu diperhatikan dalam melakukan evaluasi program menurut Provus (1971), yaitu (1) the judgment of authorities about a program, (2) the opinions a program staff, (3) the opinions of those affected by a program, (4) a comparison of actual program outcomes with expected outcomes, (5) a comparison of an executed program with its design.

Salah satu model evaluasi yang banyak digunakan oleh evaluator adalah model evaluasi CIPP (Contex, Input, Process, Product). Model evaluasi ini dikembangkan oleh Sufflebeam (1967). Model evaluasi CIPP merupakan model evaluasi komprehensif yang memiliki fungsi formatif dan fungsi sumatif. Fungsi formatif evaluasi memberikan informasi guna memperbaiki dan mengembangkan program. Sedangkan fungsi sumatif evaluasi memberikan pertimbangan untuk menentukan keberhasilan atau kelanjutan program (Stufflebeam, D.L., Coryn, 2014). Model ini merumuskan evaluasi sebagai "suatu proses menggambarkan, memperoleh, dan menyediakan informasi yang berguna untuk menilai alternatif keputusan" (Stufflebeam, 1973) dalam (Tayibnapis, 2008). Model evaluasi CIPP terdiri dari empat komponen evaluasi, yaitu evaluasi konteks, evaluasi masukan, evaluasi proses dan evaluasi produk. Evaluasi konteks untuk menelaah status objek secara keseluruhan sehingga dapat memberikan deskripsi mengenai karakteristik lingkungan (Badrujaman A, 2011). Evaluasi konteks untuk mengetahui kekuatan dan kelemahan program (Stufflebeam, D.L., Madaus, G.F., Scriven, 1983). Evaluasi input atau masukan untuk mengevaluasi kualitas masukan yang dapat menunjang ketercapaian program (Sudjana Nana dan Ibrahim, 2004). Fokus kajian evaluasi masukan meliputi sumber daya manusia, sarana dan peralatan pendukung, dana/anggaran, dan berbagai prosedur dan aturan yang diperlukan (Widoyoko, 2014). Evaluasi proses berorientasi pada seberapa jauh kegiatan program terlaksana sesuai dengan rencana. Evaluasi proses melibatkan aspek apa 
kegiatannya, siapa penanggung jawab program, dan kapan kegiatan selesai. Hasil evaluasi proses untuk mengetahui kekurangan dalam pelaksanaan program, baik strategi maupun capaian program (Stufflebeam, D.L., Coryn, 2014). Evaluasi produk untuk mengukur, menginterpretasikan, dan menilai capaian program.

Evaluasi program akan menghasilkan empat alternatif kebijakan, yaitu (1) menghentikan program, karena dipandang bahwa program tersebut tidak ada manfaatnya, atau tidak terlaksana sebagaimana diharapkan, (2) Merevisi program, karena ada bagianbagian yang kurang sesuai dengan harapan terdapat kesalahan tetapi hanya sedikit, (3) melanjutkan program, karena pelaksanaan program menunjukkan bahwa segala sesuatu sudah berjalan sesuai dengan harapan dan memberikan hasil yang bermanfaat, (3) menyebarluaskan program dengan melaksanakan program di tempat-tempat lain atau mengulangi lagi program di lain waktu, karena program tersebut berhasil dengan baik, maka sangat baik jika dilaksanakan lagi di waktu dan tempat yang lain (Arikunto \& Jabar, 2010).

Penelitian ini bermaksud untuk melakukan evaluasi program MYRES guna menjawab pertanyaan: 1) bagaimana konteks program MYRES? 2) bagaimana input (masukan) program MYRES? 3) bagaimana proses pelaksanaan MYRES? 4) bagaimana produk atau hasil yang dicapai program MYRES? Hasil penelitian ini diharapkan dapat memberikan masukan kepada Direktorat KSKK, Dirjen Pendis Kementerian Agama selaku penyelenggara program MYRES untuk keberlanjutan program MYRES yang lebih baik. Selain itu, hasil evaluasi ini juga dapat dijadikan bahan kebijakan bagi Kementerian Agama provinsi dan kabupaten serta satuan pendidikan madrasah untuk mendapatkan calon-calon peneliti yang berkualitas dan kompetitif di kalangan siswa madrasah.

\section{METODOLOGI}

\section{Model CIPP dalam Evaluasi Program MYRES}

Penelitian ini merupakan jenis penelitian evaluasi program dengan model evaluasi $C I P P$ untuk mengevaluasi program MYRES tahun
2019. Komponen dan indikator dalam evaluasi CIPP ini meliputi: pertama, evaluasi konteks yang bertujuan untuk mengetahui kesesuaian program MYRES dengan kebutuhan masyarakat. Arah evaluasi ini difokuskan pada: a) menilai landasan hukum penyelenggaraan program MYRES, dan b) kesesuaian program MYRES dengan kebutuhan masyarakat. Kedua, Evaluasi Masukan yang bertujuan untuk mengetahui kualitas masukan yang meliputi juknis, panitia, peserta, pembimbing atau mentor, pendamping, dan pembiayaan program MYRES. Ketiga, Evaluasi Proses untuk menilai implementasi tahapan kegiatan MYRES dari sosialisasi, seleksi, workshop super camp, pembinaan penelitian, dan Grand Final. Keempat, Evaluasi produk untuk mengukur, menginterpretasikan, dan menilai capaian program MYRES berdasarkan tujuan yang telah ditetapkan dalam juknis.

\section{Kriteria Evaluasi Program MYRES}

Pelaksanaan program MYRES tahun 2019 mengacu pada Surat Keputusan Dirjen Pendis Nomor 2146 Tahun 2019. Petunjuk teknis inilah yang menjadi kriteria untuk melihat keberhasilan program MYRES. Secara umum Program MYRES bertujuan untuk menumbuh kembangkan budaya meneliti di kalangan siswa madrasah. Sedangkan tujuan khusus MYRES, yaitu (1) Memotivasi siswa madrasah untuk berkreasi dalam berbagai bidang ilmu sesuai minat dan bakatnya, (2) Membangun integritas dan sikap bertanggungjawab, kemampuan berpikir logis dan analitis, kemampuan bekerja sama dalam kelompok, kemandirian, kepercayaan diri, serta keterampilan berkomunikasi dan kemampuan menulis karya ilmiah, (3) Sarana pembelajaran bagi siswa madrasah dalam menuangkan ide-ide dan gagasan kreatif yang dituangkan dalam tulisan, (4) Menumbuhkembangkan budaya meneliti di kalangan siswa madrasah, (5) Mendorong pencapaian hasil penelitian yang orisinal, berkualitas, dan kompetitif, (6) Mengembangkan potensi intelektual dan daya piker kritis bagi siswa madrasah terhadap situasi yang berkembang, (7) Menciptakan generasi muda yang berprestasi dan produktif dalam berkarya, (8) Mempersiapkan siswa madrasah menuju era revolusi industry 4.0 (Petunjuk Teknis MYRES, 2019). 
Tahapan program MYRES meliputi: (1) Pengunggahan naskah proposal secara online ke website madrasah.kemenag.go.id/MYRES2019.

Proposal yang dikirimkan belum pernah atau tidak sedang diikutkan dalam kompetisi serupa; (2) Seleksi proposal dilakukan oleh tim penilai atau juri untuk menentukan 9 (Sembilan) proposal terbaik per bidang penelitian pada setiap jenjang MTS dan MA. Penilaian proposal meliputi metode penelitian, keunikan ide dan kreativitas, potensi aplikasi, orisinalitas serta penggunaan bahasa dan teknis penulisan; (3) Pembinaan awal secara daring untuk proposal yang lolos seleksi; (4) Workshop Super camp untuk memberikan pendalaman dan pembelajaran secara substansi dan teknik penelitian; (5) Pembinaan penelitian dan penulisan laporan penelitian secara daring, dan (6) Grand Final MYRES (Petunjuk Teknis MYRES, 2019).

\section{Metode Penelitian}

Pengumpulan data penelitian dilakukan pada bulan September 2019 dengan teknik observasi, wawancara, angket, dan studi dokumentasi. Teknik observasi dilakukan terhadap benda-benda, kondisi lapangan, proses kegiatan dan perilaku orang tertentu dalam pelaksanaan Grand Final MYRES di Manado. Teknik wawancara dilakukan kepada panitia penyelenggara, pembimbing, juri, peserta, dan guru pendamping peserta MYRES untuk menggali informasi program MYRES dari komponen konteks, input, proses, dan produk. Teknik dokumentasi dilakukan dengan mencari dan mengumpulkan dokumen yang berkaitan dengan program MYRES. Angket diberikan kepada responden yang terdiri dari peserta dan guru pendamping finalis Grand Final MYRES untuk mengetahui persepsinya terhadap pelaksanaan MYRES tahun 2019. Finalis Grand Final MYRES terdiri dari 54 tim madrasah dengan jumlah peserta total sebanyak 99 orang. Finalis tim madrasah terdiri dari 2 atau 3 siswa. Setiap tim madrasah didampingi oleh 1-2 orang guru pendamping. Responden peserta finalis berjumlah 71 siswa. Sedangkan responden guru pendamping sebanyak 25 orang.

Teknik penyebaran angket dilakukan pada saat pelaksanaan Grand Final yaitu pada tanggal 16-19 September 2019. Teknik analisa data menggunakan statistik deskriptif untuk melukiskan dan menganalisis kelompok data tanpa membuat atau menarik kesimpulan atas populasi yang diamati (Arikunto dan Jabar, 2010, Suharyadi \& K., 2003). Statistik deskriptif yang digunakan adalah distribusi frekuensi, rata-rata dan angka indeks untuk menggambarkan ketercapaian program. Angka indeks menggunakan skala 1-4 dengan kategorisasi sebagai berikut: $1-1,75=$ tidak baik; $1,76-2,5=$ kurang baik; $2,51-3,25=$ baik; $3,26-4,0=$ sangat baik

\section{HASIL DAN PEMBAHASAN Evaluasi Konteks}

Evaluasi konteks dalam evaluasi program MYRES berkaitan dengan landasan hukum dan analisa kebutuhan masyarakat terhadap program. Pedoman pelaksanaan MYRES merujuk pada Surat Dirjen Pendis Nomor 2146 Tahun 2019 tentang juknis Pelaksanaan Madrasah Young Researchers Super Camp Tahun Anggaran 2019. Regulasi penyelenggaraan MYRES untuk memenuhi amanat Undang-undang sistem pendidikan nasional nomor 20 tahun 2003 (UU Sisdiknas) dan Peraturan Menteri Pendidikan Nasional (Permendiknas) nomor 39 tahun 2008 tentang pembinaan kesiswaan. Dalam UU Sisdiknas pasal (3) dijelaskan tujuan pendidikan nasional adalah untuk mengembangkan potensi peserta didik agar menjadi manusia yang beriman dan bertakwa kepada Tuhan Yang Maha Esa, berakhlak mulia, sehat, berilmu, cakap, kreatif, mandiri, dan menjadi warga negara yang demokratis serta bertanggung jawab. Tujuan pendidikan ini selaras dengan tujuan penyelenggaraan MYRES agar siswa berkreasi menghasilkan karya ilmiah, cakap dalam mengkomunikasikan hasil penelitian, mandiri, bekerjasama dan bertanggung jawab dalam melakukan penelitian (Petunjuk Teknis MYRES, 2019).

Permendiknas nomor 39 tahun 2008 dalam lampirannya memberikan arahan teknis materi pembinaan kesiswaan yang terdiri dari 10 bidang, yaitu (1) pembinaan keimanan dan ketakwaan terhadap Tuhan Yang Maha Esa, (2) pembinaan akhlak mulia, (3) pembinaan kepribadian unggul, wawasan kebangsaan, dan bela negara, (4) pembinaan prestasi akademik, seni, dan/atau olahraga sesuai minat dan bakat, 
(5) pembinaan demokrasi, hak asasi manusia, pendidikan politik, lingkungan hidup, kepekaan dan toleransi sosial dalam konteks masyarakat plural, (6) Pembinaan kreativitas, keterampilan dan kewirausahaan, (7) Pembinaan kualitas jasmani, kesehatan dan gizi berbasis sumber gizi yang terdiversifikasi, (8) Pembinaan sastra dan budaya, (9) Pembinaan teknologi informasi dan komunikasi (TIK), dan (10) Pembinaan komunikasi dalam bahasa Inggris. Salah satu materi pembinaan kesiswaan poin (6) yaitu: Pembinaan kreativitas, keterampilan dan kewirausahaan berupa meliputi mengadakan lomba program keahlian dalam bidang penelitian, kegiatan ilmiah, pameran karya inovatif dan hasil penelitian. Penyelenggaraan MYRES ini sejalan dengan materi pembinaan kesiswaan pada poin 6 dalam Permendiknas nomor 39 tahun 2008.

Dengan demikian, hasil evaluasi program MYRES pada aspek landasan hukum telah memenuhi atau sesuai dengan regulasi Undangundang nomor 20 tahun 2003 dan Permendiknas nomor 39 tahun 2008.
Indikator suatu program merupakan kebutuhan masyarakat ditandai dengan peningkatan minat dan dukungan masyarakat terhadap program. Peserta kompetisi MYRES tahun 2019 mengalami peningkatan yang sangat signifikan dari tahun 2018 yaitu sebesar $65,13 \%$. Selain peningkatan jumlah peserta, persebaran wilayah peserta MYRES juga bertambah luas. Kompetisi MYRES tahun 2019 diikuti oleh 32 provinsi di Indonesia.

Dukungan madrasah dan Kementerian Agama Provinsi serta kota/kabupaten terhadap program MYRES dikategorikan tinggi. Survei terhadap 71 finalis grand final MYRES menunjukkan bahwa mayoritas madrasahnya mendukung program MYRES (Gambar 1). Indeks dukungan madrasah terhadap MYRES sebesar 2,54 atau kategori tinggi. Beberapa bentuk dukungan madrasah kepada peserta antara lain: dispensasi waktu untuk melakukan penelitian, fasilitasi biaya penelitian, penginapan dan transpor guru pendamping karena panitia penyelenggara hanya memberikan fasilitas untuk siswa peserta finalis.

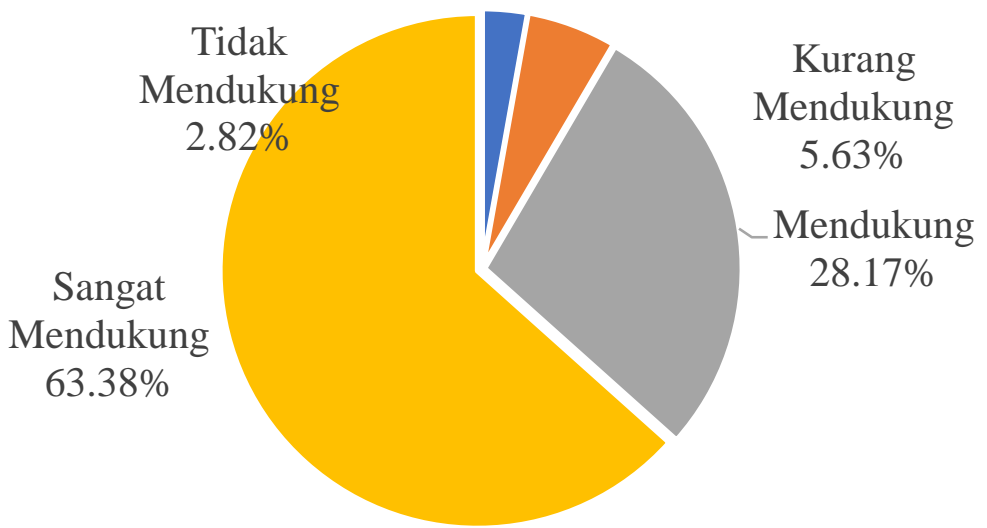

Gambar 1. Dukungan Madrasah terhadap MYRES

Kantor Wilayah (Kanwil) Kementerian Agama Provinsi juga mendukung dengan baik kompetisi MYRES. Survei pada 25 guru pendamping peserta finalis menemukan bahwa lebih dari separuh responden menyatakan Kanwil sangat mendukung program MYRES (Gambar 2). Beberapa bentuk dukungan Kanwil Kementerian Agama berupa sosialisasi, motivasi, pengarahan secara berkala, sampai kepada dukungan kostum dan fasilitas penginapan untuk pendamping. Indeks dukungan Kanwil terhadap MYRES mencapai 2,92 atau kategori tinggi. Kanwil Kementerian Agama Provinsi Jakarta, misalnya memberikan dukungan sarana berupa menyewakan televisi untuk penayangan hasil penelitian, kostum peserta dan pendamping, fasilitas penginapan, serta transpor untuk guru pendamping ke Manado (Wawancara Melda, 3 Oktober 2019).

Meskipun demikian, masih ditemukan beberapa Kanwil Kementerian Agama Provinsi tidak dapat memberikan dukungan seperti fasilitas penginapan dan transpor untuk guru pendamping peserta finalis. Sehingga madrasah yang bersangkutan harus mengeluarkan biaya yang cukup besar untuk kegiatan grand final tersebut. Pembiayaan tersebut ada yang diperoleh dari komite madrasah, namun ada juga menggunakan biaya pribadi guru yang 
bersangkutan. Berdasarkan indikator kebutuhan dan dukungan masyarakat tersebut, maka hasil evaluasi konteks menunjukkan bahwa progam MYRES sudah sesuai dengan konteks program.

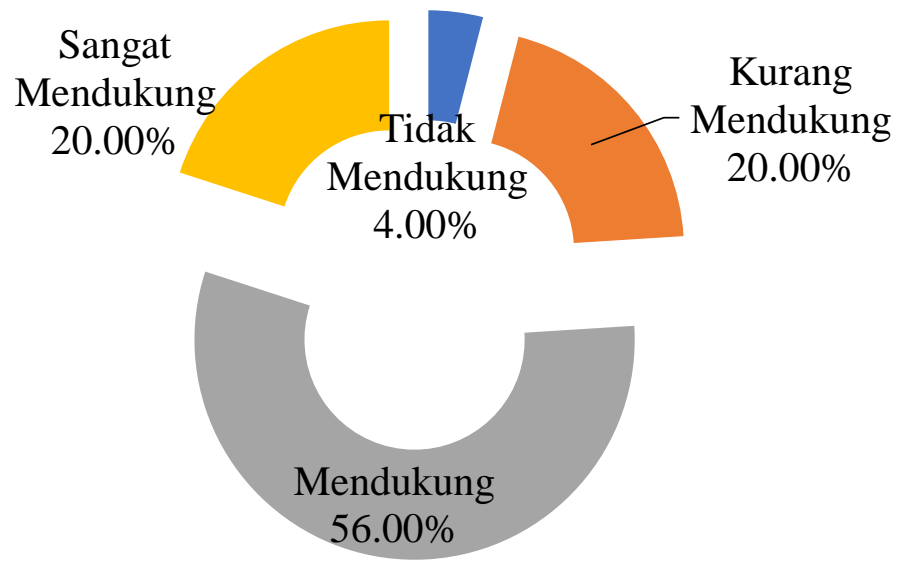

Gambar 2. Dukungan Kementerian Agama Provinsi terhadap MYRES

\section{Evaluasi Masukan}

Evaluasi masukan atau input bertujuan untuk mengetahui kualitas masukan yang mencakup: petunjuk teknis (juknis), panitia, peserta, pembimbing atau mentor, dan pembiayaan program MYRES. Petunjuk teknis (juknis) pelaksanaan MYRES merujuk pada Surat Dirjen Pendis Nomor 2146 Tahun 2019 tentang juknis Pelaksanaan Madrasah Young Researcher Super Camp Tahun Anggaran 2019. Juknis ini mencakup latar belakang program, ruang lingkup atau bidang kompetisi, persyaratan, mekanisme pelaksanaan, jadwal pelaksanaan, kriteria penilaian, tim juri, dan penghargaan bagi pemenang pada grand final MYRES. Hampir separuh responden menilai juknis pelaksanaan MYRES sudah jelas dan hampir separuh responden lagi menilai kurang jelas (Gambar 3). Konten juknis yang menjadi catatan peserta adalah adanya perubahan jadwal, konten poster dan pameran, serta kriteria penilaian grand final agar lebih rinci sehingga tidak menimbulkan multitafsir.
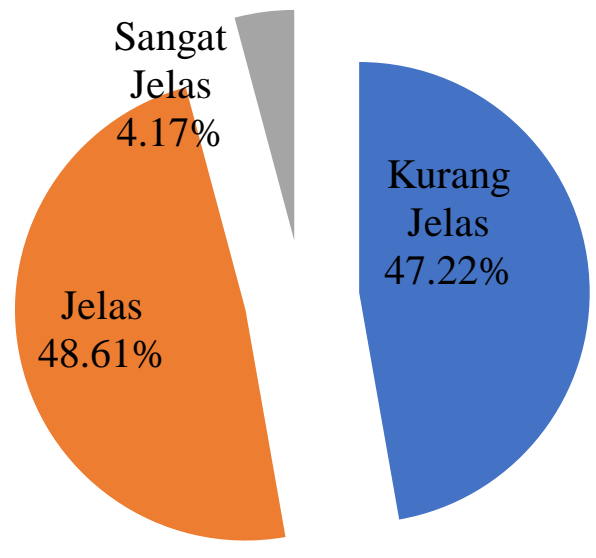

\section{Gambar 3. Petunjuk Teknis Pelaksanaan MYRES}

Panitia penyelenggara kompetisi MYRES adalah Sub Direktorat Kesiswaan pada Direktorat KSKK, Dirjen Pendis, Kementerian Agama. Aspek panitia penyelenggara mendapatkan banyak perhatian dari peserta, terutama pada pelaksanaan grand final di Manado. Panitia grand final MYRES berjumlah 4 (empat) orang dirasakan peserta dan guru pendamping kurang memadai. Penginapan yang tidak satu tempat (hotel) untuk peserta dan guru pendamping menjadikan kurangnya koordinasi antara panitia, peserta, dan guru pendamping terutama ketika ada perubahan jadwal dan tempat kegiatan. Minimnya jumlah panitia menyebabkan pelayanan yang diberikan kurang cepat dan tanggap.

Peserta kompetisi MYRES tahun 2019 sebanyak 1.018 proposal yang meliputi : 803 
proposal $(78,88 \%)$ penelitian dari siswa MTS dan 215 proposal $(21,12 \%)$ dari siswa MA. Sebagian besar peserta adalah siswa madrasah negeri $(93,81 \%)$ dan hanya sedikit saja $(6,19 \%)$ yang berasal dari siswa madrasah swasta. Peserta MYRES berasal dari seluruh provinsi di Indonesia, kecuali provinsi Nusa Tenggara Timur dan Sulawesi Utara belum berpartisipasi dalam kompetisi MYRES tahun 2019. Sepuluh provinsi yang paling banyak mengirimkan proposal penelitian adalah Provinsi Jawa Timur (285 proposal), Jawa Tengah (158 proposal), Yogyakarta (65 proposal), Jawa Barat (50 proposal), Sulawesi Tenggara (44 proposal), Sulawesi Selatan (43 proposal), DKI Jakarta (39 proposal), Sumatera Utara (39 proposal), Sumatera Selatan (39 proposal), dan Kalimantan Selatan (35 proposal).

Proposal peserta MYRES tahun 2019 terdiri dari $48,43 \%$ bidang Matematika, Sains dan Teknologi, 33,20\% bidang sosial dan humaniora, dan $18,37 \%$ bidang ilmu keagamaan. Data ini mengindikasikan bahwa kajian ilmu keagamaan kurang diminati di kalangan madrasah. Beberapa alasan yang dikemukakan guru pendamping antara lain: pertama, kurangnya pembimbing atau pendamping penelitian yang berasal dari guru rumpun Pendidikan Agama Islam (PAI), sehingga ide-ide penelitian yang dikaitkan dengan ilmu keagamaan masih terbatas. Kedua, masih terjadi dikotomi ilmu antara ilmu sains dan teknologi dengan ilmu keagamaan. Sebagian masyarakat masih menganggap bahwa penelitian adalah kegiatan ilmiah bidang sains dan teknologi yang tidak dapat dikaitkan dengan ilmu keagamaan. Ketiga, masih ada kekhawatiran terjadi kesalahan dalam penafsiran Alquran dan hadis serta hukumhukum Islam ke dalam bidang kajian penelitian. Keempat, ilmu keagamaan belum popular sebagai kajian penelitian di kalangan madrasah.

Semua proposal yang masuk mengikuti seleksi tim penilai untuk lolos ke tahap Super Camp. Dengan proses seleksi yang ketat berdasarkan kriteria penilaian, ditetapkan 54 proposal lolos ke tahap Super camp. Proposal tersebut meliputi : 27 proposal dari siswa MTS dan 27 proposal dari siswa MA yang lolos ke tahap Super camp. Sebagian besar proposal $(83,33 \%)$ adalah penelitian tim atau kolaborasi dan sisanya $16,67 \%$ penelitian individu. Sebaran 54 proposal yang lolos seleksi menurut provinsi. Peserta yang lolos seleksi tersebar pada 17 provinsi di Indonesia (Gambar 4). Provinsi Jawa Timur paling banyak mengirimkan siswanya untuk calon peneliti muda pada MYRES, disusul dengan Jawa Tengah, dan Yogyakarta.

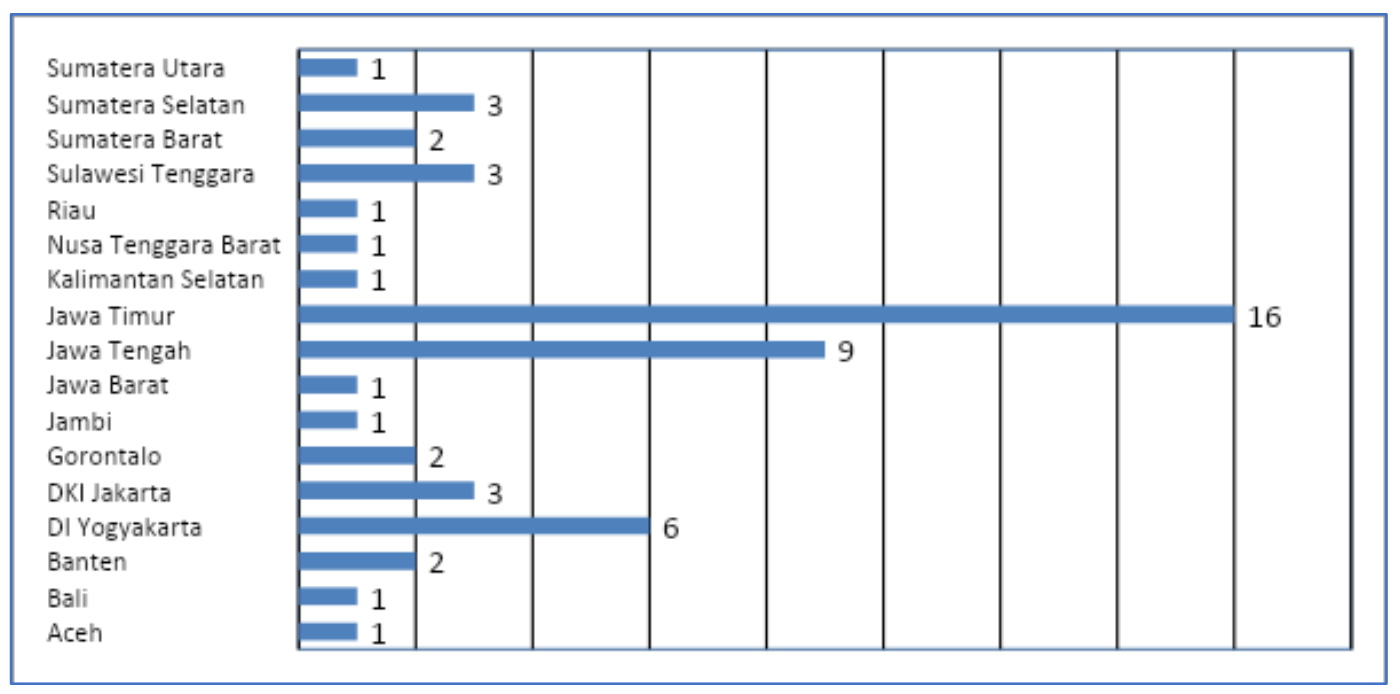

Gambar 4. Sebaran Peserta MYRES yang Lolos Seleksi

Peserta yang lolos seleksi menjadi tim peneliti siswa madrasah yang berhak mendapatkan pembimbingan penelitian dari tim pembimbing panitia yang berasal dari Universitas Negeri (UIN) Syarif Hidayatullah
Jakarta, UIN Walisongo Semarang, Institut Agama Islam Negeri (IAIN) Surakarta, Lembaga Ilmu Pengetahuan Indonesia (LIPI), dan Badan Litbang dan Diklat Kementerian Agama. Mayoritas responden mengaku bahwa 
kompetensi pembimbing sudah baik $(61,11 \%)$, $34,72 \%$ menilai kompetensinya sangat baik, dan hanya $4,17 \%$ yang menilai kurang baik. Indeks kompetensi pembimbing atau mentor mencapai angka 3,31 atau kategori sangat baik.

Penjaringan tim peneliti di kalangan siswa madrasah dilakukan oleh guru pembimbing yang sebagian besar adalah guru ekstrakurikuler kelompok ilmiah remaja (KIR) dan guru pada mata pelajaran terkait. Sebagian madrasah juga memfasilitasi peserta dengan memberikan pembimbing dari luar madrasah, 19,27\% responden menyatakan mereka diberikan pembimbing dari luar madrasah, dan $80,28 \%$ hanya menggunakan pembimbing dari madrasah. Pembimbing dari luar madrasah biasanya berasal dari dosen perguruan tinggi, seperti MTS Negeri 6 Sleman menggunakan pembimbing dari Universitas Negeri Yogyakarta, MTS Negeri 2 Kota Kediri mengundang pembimbing dari IAIN Kota
Kediri, dan MTS Negeri 1 Malang memakai mentor dari Universitas Negeri Malang.

Pembiayaan program MYRES tidak terlalu besar seperti pada anggaran Kompetensi Sains Madrasah (KSM) karena sebagian besar tahapan kegiatan dilakukan secara online melalui Website Kementerian Agama (Wawancara Yuyun, 12 September 2019). Meskipun demikian, ada komponen pembiayaan yaitu pembiayaan penelitian bagi tim peneliti yang dibebankan kepada madrasah dirasakan cukup berat karena jumlahnya yang relatif besar terutama untuk penelitian bidang sains dan teknologi. Biaya penelitian tersebut terdiri dari biaya transportasi ke lokasi penelitian, membeli materi atau alat-alat penelitian, dan biaya-biaya lain yang selama proses penelitian. Besaran biaya penelitian bervariasi dari 500 ribu rupiah hingga lebih dari 3 juta rupiah (Gambar 5).

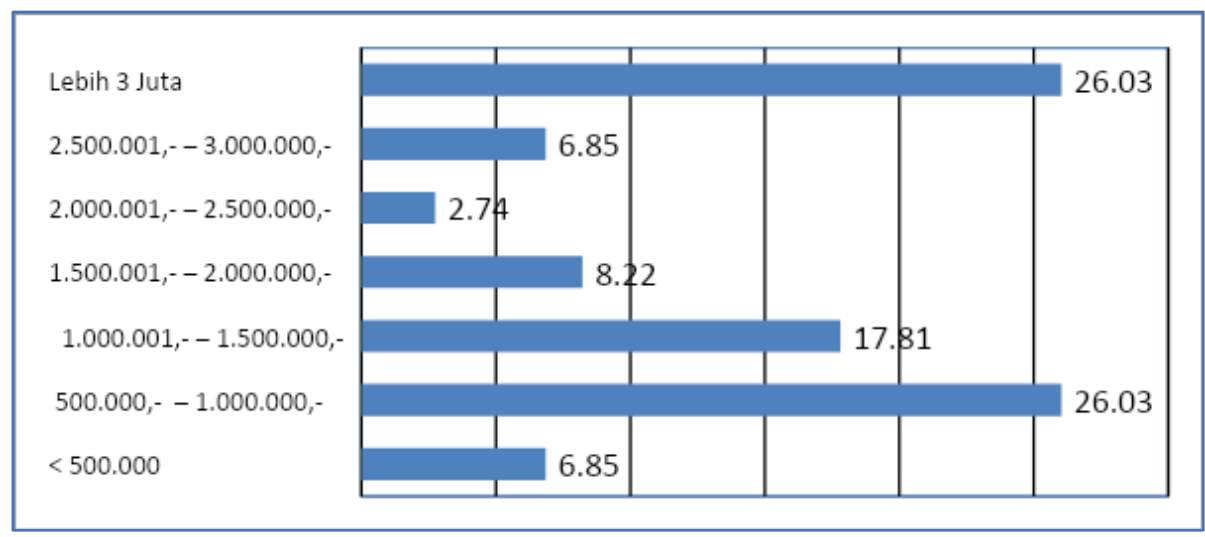

Gambar 5. Besaran Biaya Penelitian MYRES (\%)

Sumber biaya penelitian MYRES sebagian besar ditanggung oleh madrasah $(61,36 \%)$, sebagian biaya lagi bersumber dari guru pembimbing $(15,91 \%)$, orang tua peserta $(12,50 \%)$, pribadi siswa $(10,23 \%)$. Madrasah berharap agar panitia memberikan biaya untuk melakukan penelitian kepada tim peneliti madrasah yang lolos seleksi karena kemampuan finansial peserta dan madrasah berbeda-beda (Wawancara Indra, 18 September 2019).

Selain biaya penelitian, besarnya beasiswa bakat dan prestasi serta uang pembinaan sebagai hadiah bagi semua finalis juga menjadi perhatian peserta dan guru pendamping. Beasiswa bakat dan prestasi sebesar 1,6 juta rupiah untuk setiap finalis dinilai sesuai oleh $61,97 \%$ responden, sangat sesuai $(8,45 \%)$, kurang sesuai $(22,54 \%)$, dan tidak sesuai (5,63\%). Responden berharap beasiswa bakat dan prestasi nilainya dapat ditingkatkan lagi, minimal dapat menutupi seluruh biaya penelitian yang telah digunakan.

Selain memperoleh sertifikat dan medali, para pemenang atau juara Grand final Myres juga mendapatkan hadiah berupa uang pembinaan. Besaran hadiah untuk juara I sebesar 3 juta rupiah, juara II sebesar 2,5 juta rupiah, dan juara III sebesar 2 juta rupiah. Lebih dari separuh responden $(52,11 \%)$ menilai besaran hadiah tersebut sesuai, sebanyak $8,45 \%$ responden mengaku sangat sesuai, sebagian kecil responden saja yang mengaku kurang sesuai $(28,17 \%)$, tidak sesuai $(5,63 \%)$. Namun 
sebagian peserta dan guru pendamping berharap uang pembinaan yang diberikan kepada para pemenang besarannya lebih besar lagi sebesar 5-10 juta rupiah karena MYRES adalah kompetisi tingkat nasional. Selain itu, besaran hadiah juga sebaiknya dibedakan sesuai jenjang pendidikan MTS dan MA.

\section{Evaluasi Proses}

Evaluasi proses kompetisi MYRES bertujuan untuk menilai sejauhmana implementasi tahapan kegiatan MYRES yang meliputi: sosialisasi, seleksi, workshop, pembinaan penelitian dan penulisan laporan penelitian, dan Grand Final MYRES. Sosialisasi program MYRES tahun 2019 dimulai pada bulan Mei 2019. Sosialisasi dilakukan melalui Website Kementerian Agama, Surat Edaran Direktur Madrasah kepada Kanwil Kementerian Agama Provinsi dan Kota/Kabupaten, serta media sosial. Sebagian besar responden guru pendamping finalis $(36,92 \%)$ mengaku mendapatkan informasi kompetisi MYRES dari madrasah (kepala madrasah atau guru pembimbing KIR) dan 35,38\% responden dari Website Kementerian Agama, Kanwil Kementerian Agama Provinsi (12,31\%), media sosial (9,23\%), dan Kementerian Agama kota/kabupaten $(6,15 \%)$.

Sosialisasi kegiatan MYRES pada bulan Mei 2019 bertepatan dengan bulan Ramadhan dinilai kurang efektif karena sebagian madrasah sudah libur hari raya Idul Fitri 1440 Hijriyah, sehingga madrasah kurang maksimal dalam melakukan penjaringan dan pembimbingan calon peneliti siswa madrasah untuk mengikuti kompetisi MYRES (Wawancara Imam, 26 September 2019; Tini 27 September 2019). Responden berharap sosialisasi MYRES dilakukan pada awal tahun agar madrasah dapat mempersiapkan lebih maksimal untuk penjaringan dan pembimbingan peserta kompetisi ini.

Proses seleksi proposal penelitian kompetisi MYRES dilakukan oleh tim juri terhadap semua proposal penelitian yang masuk ke

Website https://madrasah.kemenag.go.id/MYRES2019 sebanyak 1.018 proposal. Kriteria proposal terbaik berdasarkan pada beberapa aspek, yaitu ide dan orisinalitas penelitian, kesesuaian antara rumusan masalah/pertanyaan, pemilihan metode penelitian yang akan digunakan, dan nilai tambah atau manfaat dari penelitian (Petunjuk MYRES, 2019). Peningkatan yang signifikan pada jumlah proposal yang mengikuti kompetisi MYRES tahun 2019 menjadi tantangan tim juri dalam menentukan 54 proposal terbaik berdasarkan kriteria yang telah ditetapkan. Sehingga dibutuhkan kuantitas dan kualitas tim juri MYRES

Peserta yang lolos seleksi sebanyak 54 proposal mengikuti Workshop Super Camp untuk memperoleh pembekalan research skills dari narasumber sekaligus menjadi pembimbing atau mentor pada pelaksanaan penelitian. Workshop ini diselenggarakan selama 4 (empat) hari dari tanggal 3-5 Juli 2019 di hotel Ara, Serpong, Banten. Narasumber atau mentor Super camp ini berasal dari peneliti LIPI, Universitas Islam Negeri (UIN) atau Institut Agama Islam Negeri (IAIN) dan Badan Litbang dan Diklat Kementerian Agama. Proses seleksi melalui super camp ini pada awalnya akan memilih 18 proposal terbaik dari 54 proposal, namun karena semua proposal dinilai memiliki kualitas yang baik menurut tim juri, maka semua proposal dinyatakan lolos untuk mengikuti grand final MYRES (wawancara Yuyun, 12 September 2019).

Hasil survei menunjukkan bahwa pelaksanaan super camp berjalan sangat baik $(21,13 \%)$, baik $(70,42 \%)$, dan kurang baik $(8,45 \%)$. Indeks ketercapaian workshop berada pada angka 3,13 atau kategori baik. Masukan responden untuk kegiatan workshop Super camp antara lain: agar pelaksanaannya sesuai jadwal dan guru pendamping peserta diberikan fasilitas yang sama, baik dalam biaya akomodasi maupun transportasi.

Pembimbingan secara daring kepada peserta diberikan selama kurang lebih satu bulan dari bulan Juli sampai Agustus 2019. Selama proses pembimbingan daring peserta dapat berkonsultasi dengan mentor atau pembimbing melalui media sosial. Menurut pengakuan responden peserta, 21,13\% responden menilai bahwa proses mentoring secara daring berlangsung sangat baik, 70,42\% menilai baik, $8,45 \%$ responden menilai kurang baik, 2,74\% menilai tidak baik. Indeks ketercapaian pembimbingan secara daring 
sebesar 3,11 atau kategori baik. Beberapa masukan untuk perbaikan mentoring daring antara lain: jadwal pembimbingan lebih intensif, perlunya bimbingan rutin bersamasama dengan peserta lain, bimbingan tatap muka jarak jauh melalui video conference, dan bimbingan terhadap guru pembimbing dari madrasah agar terjadi satu kesepahaman antara pembimbing dari panitia dan madrasah.

Grand Final MYRES tahun 2019 diselenggarakan di kota Manado, provinsi Sulawesi Utara selama 4 hari dari tanggal 16 19 September 2019. Rangkaian kegiatan Grand Final meliputi : pembukaan oleh Menteri Agama Lukman Hakim Saefuddin, Expo atau pameran hasil penelitian, sharing moment, dan ujian presentasi.

Expo atau pameran hasil penelitian peserta menyajikan hasil penelitian berupa poster dan video profil penelitian yang berdurasi 3-5 menit. Pameran dilaksanakan di gedung IAIN Manado. Hasil survei terhadap responden peserta menemukan bahwa pelaksanaan Expo MYRES berjalan sangat baik (14,08\%), baik $(60,56 \%)$, dan kurang baik (25,35\%). Beberapa masukan untuk Expo antara lain: ruangan expo sebaiknya di hall besar, posisi semua stand strategis, juknis Expo lebih detail dan mengurangi revisi secara mendadak, adanya modifikasi konten expo seperti souvenir, pakaian adat, dan makanan khas daerah sebaiknya diatur dalam Juknis karena dapat mempengaruhi subjektivitas juri dalam penilaian.

\section{Rangkaian kegiatan Grand Final} selanjutnya adalah ujian presentasi yang dilakukan pada hari berikutnya setelah Expo. Ujian presentasi dilaksanakan secara tertutup dengan tim juri dan urutan nomor ujian diundi. Namun pada pelaksanaannya terdapat perbedaan teknis ujian yaitu : bidang sains teknologi dan ilmu sosial humaniora melakukan ujian secara tertutup, sedangkan bidang ilmu keagamaan ujiannya terbuka untuk semua finalis. Ruang ujian terpisah untuk setiap bidang. Pelaksanaan ujian ini memerlukan durasi yang cukup lama terutama untuk bidang sains teknologi dari pukul 08.00 WIB - 17.00 WIB.

Secara keseluruhan, hasil survei kepada finalis menggambarkan bahwa pelaksanaan
Grand Final berjalan sangat baik $(26,76 \%)$, baik $(61,97 \%)$, dan kurang baik $(11,27 \%)$. Beberapa masukan peserta dan guru pendamping antara lain: penginapan peserta dan guru pendamping satu tempat untuk memudahkan koordinasi, lokasi pameran dan ujian presentasi agar tidak terlalu jauh dengan lokasi penginapan, transparansi hasil penilaian, mentor dan tim penilai sebaiknya orang yang berbeda untuk menghindari subjektivitas penilaian, standarisasi ujian presentasi, jumlah panitia ditambah untuk meningkatkan pelayanan yang prima pada pelaksanaan Grand Final MYRES.

Grand Final MYRES menghasilkan 3 (tiga) pemenang atau juara untuk setiap bidang dan jenjang sehingga total sebanyak 9 (Sembilan) juara ditambah 2 (dua) juara Expo berdasarkan pengunjung stand pameran yang terbanyak. Para juara MYRES untuk tiap jenjang MTS adalah sebagai berikut: juara bidang Saintek, yaitu MTsN 1 kota Malang (I), MTsN Sleman (II), dan MTsN 1 Kab Malang (III); bidang Keagamaan MTsN 7 Model Jakarta (I), MTsN 1 Kota Pasuruan (II), dan MTsN Kab Malang (III); bidang sosial humaniora (MTsN 4 Sidoarjo (I), MTsN 2 Kota Kediri (II), dan MTsN 1 Kab Malang (III). Para juara MYRES untuk tingkat MA bidang Saintek adalah: MAN 1 Yogyakarta (I), MAN IC Gorontalo (II), MAN 2 Kudus (III); bidang Keagamaan MA Darus Salam Ciamis (I), MAN 3 Palembang (II), MAN 1 Banda Aceh (III); dan bidang sosial humaniora (MAN 1 Tanah Laut Kalsel (I), MAN 1 Kota Kendari (II), MAN IC Jambi (III). Sedangkan juara Expo MYRES adalah MTsN 3 Jakarta Selatan dan MAN 1 Banyuwangi.

Juara MYRES tahun 2019 bidang ilmu keagamaan tingkat MTS, dua di antaranya mengambil tema teknologi yang dikaitkan dengan ilmu keagamaan yang berjudul "Wadidaw (wayang digital dakwah) sebagai media dakwah agama Islam pada materi silaturahim di MI PKP Jakarta Islamic School", oleh siswa MTS N 7 Model Jakarta dan "Pembuatan Mobile Augmented Reality to Islamic Garden dalam upaya mewujudkan generasi milenial berbudaya lingkungan dan berakhlak Qur'ani" oleh siswa MTS N 1 Kota Pasuruan, Jawa Timur. Sedangkan juara MYRES bidang ilmu keagamaan lainnya 
berjudul "Pengaruh tradisi shalat tarawih super kilat di pondok pesantren salafiyah Shirotul Fuqoha terhadap rasa semangat beribadah kalangan pemuda" oleh siswa MTs N 1 kab Malang, "Islam Moderat: Konsep Dan Implementasinya Di Pondok Pesantren Darussalam Ciamis" oleh siswa MA Darus Salam Ciamis, "Deradikalisasi dan Moderasi Madrasah dengan Pemanfaatan Moderat Corner untuk Indonesia Damai" oleh siswa MAN 3 Palembang, dan "Implementasi Hukum Jinayat terhadap Isu Diskriminasi Gender di Provinsi Aceh" oleh siswa MAN 1 Banda Aceh.

\section{Evaluasi Produk}

Evaluasi produk program MYRES difokuskan untuk menilai sejauh mana tingkat ketercapaian tujuan program. Hasil evaluasi ini akan menjadi masukan bagi stakeholders untuk menentukan keberlanjutan program (Widoyoko, 2014). Tujuan program MYRES secara umum yang tercantum dalam Juknis MYRES tahun 2019 adalah untuk menumbuhkembangkan budaya meneliti di kalangan siswa madrasah.

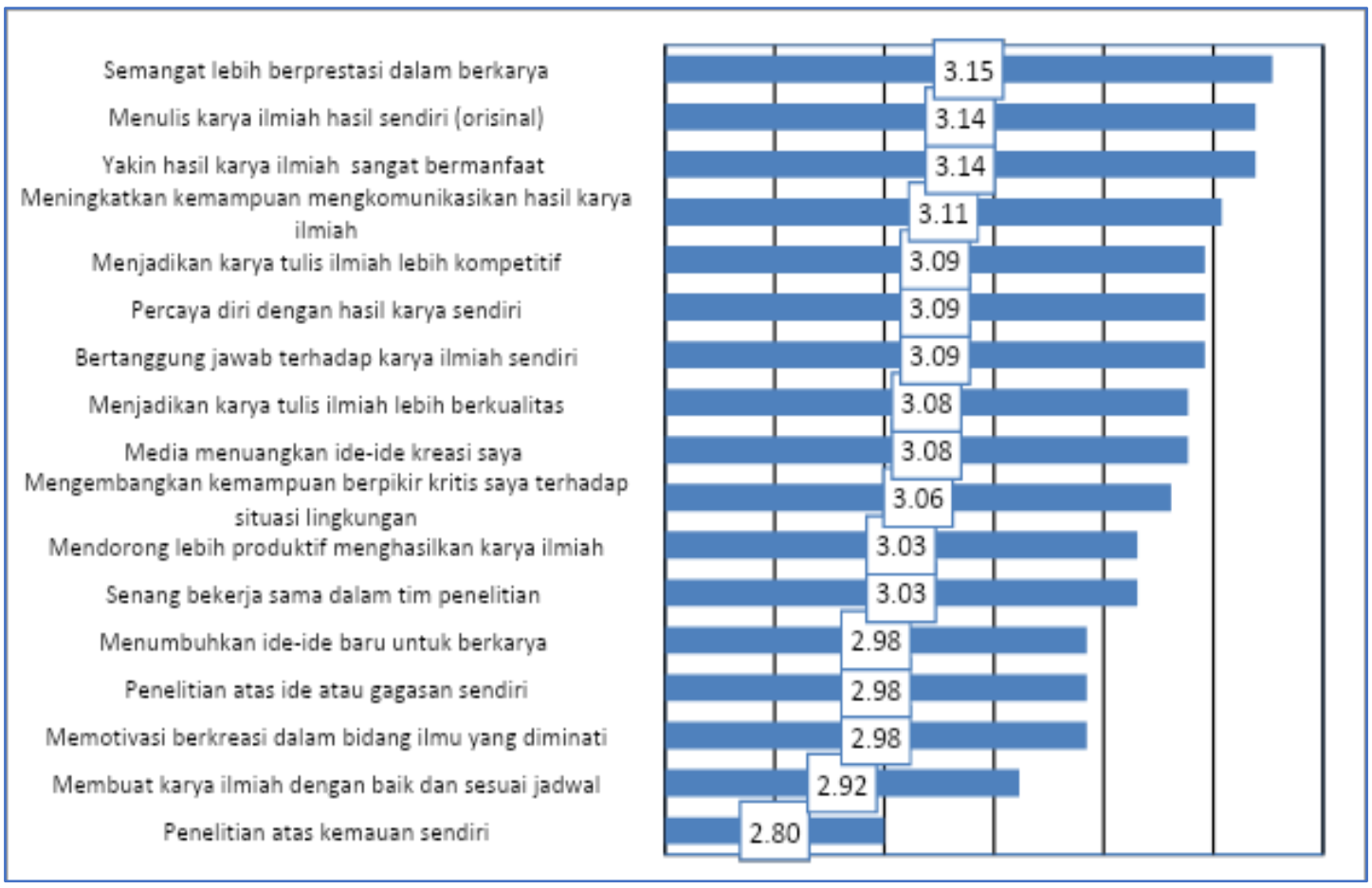

Gambar 6 Indeks Ketercapaian Tujuan Program MYRES

Tingkat ketercapaian tujuan program digambarkan dengan indeks (lihat Gambar 11). Semakin tinggi indeks menggambarkan semakin tinggi tingkat ketercapaiannya. Tingkat ketercapaian tujuan program memiliki indeks 2,80 hingga 3,15 (skala 1-4) yang berarti bahwa secara umum tujuan MYRES untuk menumbuhkembangkan budaya meneliti di kalangan siswa madrasah sudah tercapai dengan baik. Tiga indikator yang paling tinggi tingkat ketercapaiannya adalah: tingkat ketercapaian semua aspek tujuan MYRES berada pada kategori baik. Tiga tujuan yang paling tinggi indeksnya adalah pada indikator bahwa MYRES menumbuhkan semangat untuk lebih berprestasi dalam membuat karya ilmiah, mendorong responden untuk menulis karya ilmiah hasil sendiri atau orisinal, meningkatkan kemampuan mengkomunikasikan hasil karya ilmiah. Sedangkan indikator yang masih perlu ditingkatkan adalah bahwa siswa peserta MYRES mampu melakukan penelitian atas kemauan sendiri, membuat karya ilmiah dengan baik dan sesuai jadwal, memotivasi berkreasi dalam bidang ilmu yang diminati, melakukan penelitian atas ide atau gagasan sendiri $(2,98)$, dan menumbuhkan ide-ide baru untuk menghasilkan karya ilmiah selanjutnya (Gambar 6).

Hasil evaluasi produk tersebut membuktikan bahwa MYRES sebagai salah satu program unggulan untuk menumbuhkan budaya meneliti di kalangan siswa madrasah telah tercapai dengan baik. Beberapa juara 
MYRES tahun 2019 merupakan siswa dari madrasah berbasis riset atau penelitian yang menjadikan penelitian sebagai mata pelajaran wajib, mata pelajaran peminatan, maupun muatan lokal. Beberapa madrasah tersebut, misalnya MTsN 6 Sleman memasukkan mata pelajaran penelitian sebagai mata pelajaran peminatan (Wawancara Indra, 17 September 2019), MAN 2 Kudus merupakan madrasah berbasis riset sejak tahun 2013 mewajibkan riset sebagai mata pelajaran wajib bagi semua siswa (Wawancara Royana, 17 September 2019), dan MAN 1 Yogyakarta menjadikan riset sebagai muatan lokal.

\section{PENUTUP}

Berdasarkan hasil evaluasi dan pembahasan pada tahapan konteks, input, proses, dan produk di atas, maka dapat ditarik kesimpulan sebagai berikut. Pertama, hasil evaluasi konteks diperoleh bahwa Program MYRES sesuai dengan amanat Undang-undang Nomor 20 Tahun 2003 tentang Sistem Pendidikan Nasional dan Permendiknas nomor 39 tahun 2008 tentang pembinaan kesiswaan melalui kompetisi kegiatan ilmiah dan pameran karya inovatif serta hasil penelitian. Program MYRES merupakan kebutuhan masyarakat yang banyak diminati oleh kalangan madrasah dan didukung oleh Kementerian Agama baik tingkat kota/kabupaten maupun Provinsi. Hasil evaluasi konteks menyarankan agar dukungan Kementerian Agama tingkat kota/kabupaten dan provinsi semakin ditingkatkan.

Kedua, hasil evaluasi input secara umum berada pada kategori baik. Beberapa catatan untuk evaluasi input antara lain: juknis lebih rinci, panitia Grand Final jumlahnya ditambah, pembiayaan penelitian bagi peserta dibebankan kepada panitia, beasiswa bakat dan prestasi serta uang pembinaan untuk para pemenang Grand Final besarannya dinaikkan dan dibedakan sesuai jenjang MTS dan MA.

Ketiga, hasil evaluasi proses secara umum semua tahapan MYRES berjalan baik, dengan beberapa masukan: durasi sosialisasi lebih panjang, pelaksanaan kegiatan sesuai jadwal, perlunya bimbingan daring bersama semua tim peneliti peserta dengan mentornya, jadwal bimbingan daring lebih intensif, perlunya satu kesepahaman antara mentor dengan guru pembimbing, serta standarisasi expo dan ujian presentasi

Keempat, hasil evaluasi produk membuktikan bahwa tujuan MYRES untuk menumbuhkembangkan budaya meneliti pada siswa madrasah secara umum tercapai dengan baik. Indikator yang paling kuat tingkat ketercapaiannya adalah MYRES dapat menumbuhkan semangat untuk lebih berprestasi dalam membuat karya ilmiah, mendorong untuk menulis karya ilmiah hasil sendiri, meningkatkan kemampuan mengkomunikasikan hasil karya ilmiah. Sedangkan aspek tujuan program yang perlu ditingkatkan meliputi : melakukan penelitian atas kemauan sendiri, membuat karya ilmiah dengan baik dan sesuai jadwal, memotivasi berkreasi dalam bidang ilmu yang diminati, melakukan penelitian atas ide atau gagasan sendiri, dan menumbuhkan ide-ide baru untuk menghasilkan karya ilmiah selanjutnya.

Rekomendasi hasil evaluasi program MYRES adalah: Direktorat KSKK, Dirjen Pendis Kementerian Agama agar melanjutkan program MYRES sebagai program unggulan untuk menumbuhkembangkan budaya meneliti di kalangan siswa madrasah, Badan Litbang dan Diklat Kementerian Agama agar melibatkan penelitinya untuk melakukan pembinaan penelitian kepada madrasah terutama memberikan kajian penelitian bidang ilmu keagamaan yang kurang diminati madrasah dan melakukan evaluasi terhadap berbagai program Dirjen Pendis untuk menilai efektivitas program, Kementerian Agama Provinsi agar mendorong kerjasama dengan perguruan tinggi setempat untuk pembinaan penelitian atau kolaborasi penelitian, dan Madrasah agar bermitra dengan perguruan tinggi setempat untuk meningkatkan kualitas penelitian melalui peningkatan sumber daya manusia maupun penggunaan fasilitas penelitian atau laboratorium.

\section{UCAPAN TERIMA KASIH}

Peneliti mengucapkan terima kasih kepada semua pihak yang telah membantu proses pengumpulan data penelitian ini. Terima kasih kepada Kepala Balai Litbang Agama Jakarta Dr. Nurudin, M.Si yang telah menugaskan peneliti untuk mengevaluasi 
program Madrasah Young Researchers Super Camp (MYRES) sebagai salah satu program unggulan Direktorat KSKK, Dirjen Pendis Kementerian Agama. Ucapan terima kasih kepada Kepala Seksi Kesiswaan Direktorat KSKK, tim juri, peserta atau siswa madrasah, guru pembimbing dan pendamping peserta siswa madrasah, dan semua pihak lain yang menjadi bagian dalam proses penelitian ini

\section{DAFTAR PUSTAKA}

Arikunto, S., \& Jabar, C. S. A. (2010). Evaluasi Program Pendidikan: Pedoman Teoretis Praktis bagi Mahasiswa dan Praktisi Pendidikan (Edisi Kedua). Jakarta : Bumi Aksara.

Badrujaman A. (2011). Teori dan Aplikasi Evaluasi Program Bimbingan Konseling. Jakarta: Indeks.

Beritaekspres.com. (2015). Prestasi Madrasah Kian Menonjol, 9 Hasil Penelitian Siswa MTsN 2 Kediri Tercatat di HKI. 31 Juli 2015.

http://www.beritaekspres.com/2015/07/3

1/prestasi-madrasah-kian-menonjol-9hasil-penelitian-siswa-mtsn-2-kediritercatat-di-hki/ (diakses, 1 Nopember 2019).

Handoko, L. T. (2019). Inilah Pemenang Kompetisi Ilmiah LIPI Tahun 2019. 26 Oktober 2019. http://lipi.go.id/berita/Inilah-PemenangKompetisi-Ilmiah-LIPI-Tahun2019/21839 (diakses, 1 November 2019)

Hasanah, F. (2017). Inilah Hasil Riset Siswa Madrasah di Malang Yang Berhasil Raih Penghargaan Pada Ajang IYIA 2017. 04 Oktober 2017. https://www.goodnewsfromindonesia.id/ 2017/ 0/04/inilah-hasil-penelitian-siswamadrasah-di-malang-yang-berhasil-raihpenghargaan-pada-ajang-iyia-2017/ (diakses 7 Februari 2020)

Hidayati, Umul. (2019). Inovasi Madrasah Melalui Penyelenggaraan Madrasah Riset. EDUKASI: Jurnal Penelitian Pendidikan Agama Dan Keagamaan. Volume 17(3), 2019, 238-255. https://doi.org/10.32729/edukasi.v17i3.6 36
Ibnu Salman. (2016). Evaluasi Program Ekstrakurikuler Seni Keagamaan Di MAN 8 Jakarta. Penelitian Keagamaan Dan Kemasyarakatan (PENAMAS). Volume 29, Nomor 2, Juli-September 2016

Maarif, F. (2020). Siswa Madrasah Raih Prestasi di Kompetisi Penelitian Internasional.

http://www.monitorday.com/siswamadrasah-raih-prestasi-di-kompetisipenelitian-internasional (diakses Februari 2020)

Oebaidillah, S. (2018). Kompetisi Sains Madrasah 2018 Terima Ratusan Proposal Peserta. 22 Mei 2018. https://mediaindonesia.com/read/detail/1 62549-kompetisi-sains-madrasah-2018terima-ratusan-proposal-peserta (diakses 26 Februari 2020)

Stufflebeam, D.L., Coryn, C. L. . (2014). Evaluation: Theory, Models, \& Application (Second Edition). San Fransisco: Jossey-Bass.

Stufflebeam, D.L., Madaus, G.F., Scriven, M. . (1983). Evaluation Models: Viewpoints on Educational and Human Service Evaluation. Boston: Kluwer-Nijhoff Publishing.

Sudjana Nana dan Ibrahim. (2004). Penelitian dan Penilaian Pendidikan. Bandung: Sinar Baru Algensindo.

Tayibnapis, F. Y. (2008). Evaluasi Program dan Instrumen Evaluasi untuk Program Pendidikan dan Penelitian. Jakarta: Rineka CIpta.

Widoyoko, S. E. P. (2014). Evaluasi Program Pembelajaran: Panduan Praktis bagi Pendidik dan Calon Pendidik. Yogyakarta: Pustaka Pelajar.

Wisnubro. (2019). MAN II Malang Raih Emas dan Perunggu Olimpiade Penelitian Siswa Indonesia 2019. https://jpp.go.id/humaniora/pendidikan/3 38063-man-ii-malang-raih-emas-danperunggu-olimpiade-penelitian-siswaindonesia-2019 (diakses 1 Nopember 2019) 
Yunelia, I. (2019). Gara-gara Daun Sengon Siswa Kediri Ini Terbang ke Amerika. 23 Mei 2019. https://www.medcom.id/pendidikan/inspi rasi-pendidikan/nbwQ6QEK-gara-garadaun-sengon-siswa-kediri-ini-terbangke-amerika (diakses 1 Nopember 2019)

Peraturan Perundang-undangan

Direktorat Jenderal Pendidikan Islam. 2019. Petunjuk Teknis Kompetisi Sains Madrasah Tahun 2019

Peraturan Menteri Pendidikan Nasional Nomor 39 Tahun 2008 Tentang Pembinaan Kesiswaan

Surat Dirjen Pendis Nomor 2146 Tahun 2019 tentang Petunjuk Teknis (juknis) Pelaksanaan Madrasah Young Researcher Super Camp Tahun Anggaran 2019

$\begin{array}{crr}\text { Undang-Undang } \quad \text { Nomor } & 20 \quad \text { Tahun } \\ 2003 \text { Tentang Sistem } & & \text { Pendidikan } \\ \text { Nasional } & & \end{array}$

Wawancara

Wawancara Yuyun, Kepala Seksi (Kasi) Kesiswaan Direktorat KSKK, 12 September 2019

Wawancara Royana, MAN 2 Kudus, 17 September 2019

Wawancara Yani Kasi Pendidikan Madrasah Kanwil Kementerian Agama Provinsi Kepulauan Riau dan Ima Kasi Pendis Kanwil Maluku, 17 September 2019

Wawancara Indra, MTSN 6 Sleman, 18 September 2019

Wawancara Imam, MTS N 1 Tangerang, 26 September 2019

Wawancara, Tini, MAN IC Serpong, 27 September 2019

Wawancara Melda, MTSN 7 Model Jakarta, 3 Oktober 2019. 